\title{
INVESTIGATING THE ANTIBACTERIAL ACTIVITY OF ETHANOL EXTRACT OF THE MEDICINAL PLANT RUTA GRAVEOLENS
}

\author{
Aya Shamal Al-Muffti, Muna Badee’a Abdulaziz ${ }^{*}$, Veman AbobaKerKhalid ${ }^{* *}$ \\ and OMER AYOB OMER ${ }^{* * *}$ \\ *Dept. of Pharmacy, Duhok Polytechnic University, Kurdistan Region-Iraq \\ *** Ministry of Education, Kurdistan Region-Iraq \\ **** Dept. of Health Inspection, Preventive Health, Kurdistan Region-Iraq
}

(Received: May 10, 2021; Accepted for Publication:, June 28, 2021)

\begin{abstract}
Ruta graveolens is a commonly used curative plant and indigenous to the Mediterranean region. In the present study, the ethanolic extraction of $\boldsymbol{R}$. graveolens leaves and stems was tested for antibacterial effects against Enterococcus faecalis, Staphylococcus aureus, Streptococcus pyogenes, Escherichia coli , Pseudomonas aeruginosa .The leaves $(60 \mathrm{~g})$ and stems $(60 \mathrm{~g})$ of $R$. graveolens were collected; shade dried and powdered using a grinder. After soaking the powder in $200 \mathrm{ml}$ of $96 \%$ ethanol for 24 hours and filtering it, the precipitant was air dried and $100 \mathrm{ml}$ of distilled water was added to it. Both leaves and stems extracts showed inhibitory properties on gram negative and gram positive bacteria. S. pyogenes and $S$. aureus were strongly affected by the stems extract while $E$.coli had the highest inhibition zones among the bacteria which were treated with the leaves extract. The aim of the present study is to estimate the antibacterial efficacy of $\boldsymbol{R}$. graveolens against bacterial isolates and that could open the possibility for the development of novel antibiotics.
\end{abstract}

KEYWORDS : Ruta graveolens, Antimicrobial, Antibacterial, Ethanol extract, Pathogenic bacteria , Medicinal herb

\section{INTRODUCTION}

$\mathrm{H}$ erbal medicines have been commonly used around the world for centuries, especially in developing countries where they combine it with synthetic drugs. Ruta graveolens is one of the widely used medicinal herbs; commonly known as "Rue" or "Sudab" in some countries of Asia and belongs to the family Rutaceae. The shrub-like evergreen plant is native to southeastern Europe. It has strong smelling and a bitter flavor. The stem is woody at the base and foliage is bluish-green, 2-3 pinnate and alternate (Ríos , 2015; Tobyn et al., 2011 ).

The plant has been known as pain reliever and curing dermatitis, eczema, inflammation, rheumatic disease, fibromyalgia, ulcers, and acts as abortion-inducing herb, insectifuge and antitoxin (Fadlalla et al., 2011; Ríos, 2015; Woo et al.,2012 ). Moreover, the volatile oils of $R$. graveolens showed curative treatment for gastrointestinal crumps after being mixed with water and sugar and then taken (Ravindran et al., 2012). However, therapeutic dosages of $R$. graveolens cause sleep disturbance, depression, vertigo, muscular spasm and weakness. In addition, it could lead to photoirritation, nephrotoxicity and hepatotoxicity (Aronson, 2016).

Previous studies showed that the plant was noticed to reduce spermatogenesis in Wistar rats. Rahim et al. (2009) demonstrated that $R$. graveolens ethanolic extract decreases the level of testosterone hormone and motility of sperms. Sailani \& Moeini (2007) suggested that the extract could have an effect on the pituitary gland and lead to a decrease in androgen production which is responsible for sperm production. The effect is not only limited to male rats but it was found that chloroform extract of $R$. graveolens significantly reduces fertility in female rats (Kong et al., 1989). Additionally, Nasirinezhad et al. (2016) stated that the alcohol extract of $R$. graveolens does not affect the levels of follicle stimulating hormone (FSH) and luteal hormone (LH) and could help in birth control. The mildly toxic plant has shown therapeutic action, however, caution is needed especially in case of long term 
consumption, besides that self- treatment is not recommended (Freire et al., 2010).

The phytochemical screening of $R$. graveolens documented that the plant has primary and secondary metabolites. The secondary metabolites mainly include bioactive compounds such as phenolics, flavonoids, alkaloids, terpenoids, glycosides, diterpenes, triterpenes. The secondary metabolites have been known to have defense mechanisms against a wide range of pathogens and pests (Amabye \& Shalkh, 2015). $R$. graveolens has been also found to protect DNA strands from breakage and potential mutations, besides its inhibitory action against the proliferation of cancer cells (Fadlalla et al., 2011; Ríos, 2015). Researchers have demonstrated the action of the $R$. graveolens essential oils and extracts as significant antimicrobial agents. They reported the antibacterial action against a variety of bacterial pathogens; the examined parts of the plants were either aerial parts together or leaves.

Fewer studies have investigated the action of stems. Pandey et al. (2011) were the first to document the inhibitory action of the $R$. graveolens stem against bacteria and fungi. They found that ethanol, methanol, chloroform and aqueous extracts of the stem have significant antibacterial and antifungal action. In contradiction to Ahmadi et al. (2012), where they did not observe any antibacterial effect of aqueous and ethanol $70 \%$ extract on pathogenic bacteria. They attributed their results either to the type of the used extract or the bacterial strain that showed resistance to the tested antibiotics.

On the other hand, Reddy et al. (2016) stated the importance of $R$. graveolens essential oils, where they examined the action of oils of aerial parts on gram negative and gram positive bacteria and also against fungi and yeast.

The aim of this study is to determine the antibacterial action of the ethanol extracts of leaves and stems against gram negative and gram positive bacterial strains.

\section{MATERIALS AND METHOD}

\section{- Bacterial specimens:}

The bacterial samples (P. aeruginosa, E.coli, $S$. aureus, E. faecalis, and $S$. pyogenes) were collected from Azadi hospital and cultured on nutrient, blood, and MacConkey agar. The study was conducted in the research laboratory of the Duhok Technical Institute, Duhok Polytechnic University.

\section{-Collection of Ruta graveolens and} preparation of the ethanol extract:

The medicinal plant $R$. graveolens was obtained from a local plant nursery in Duhok governorate, Kurdistan region of Iraq and identified in the research laboratory of the Duhok Technical Institute. The $(60 \mathrm{~g})$ of stems and $(60 \mathrm{~g})$ of leaves were separated; shade dried and powdered using a grinder. Each powder was soaked in $200 \mathrm{ml}$ of $96 \%$ ethanol for 24 hours and filtered through layers of gauze. The filtrate was subsequently left to dry at room temperature. The stock solution was prepared by adding $100 \mathrm{ml}$ of distilled water to the dried filtrate and the concentration 20,40,60, 80 and $100 \mathrm{mg} / \mathrm{ml}$ were used in the study (Harish et al., 2014).

\section{-Well diffusion method:}

According to Balouiri et al. (2016), the agar diffusion method was performed by using Mueller Hinton agar, the recommended growth medium for antimicrobial susceptibility tests. A number of wells were made on each agar plate using sterile glass tubes. After the bacterial isolates have been swabbed uniformly on plates, the wells were filled with drops of each concentration of the ethanol extract besides adding tetracycline $10 \mathrm{mg}$ discs as positive control and distilled water as negative control. Finally the plates were left for 15 minutes at room temperature and then incubated at $37^{\circ} \mathrm{C}$ for $24 \mathrm{hrs}$ and the inhibition zones were measured in $\mathrm{mm}$.

\section{RESULTS AND DISCUSSION}

Different communities have been using the medicinal herbs for centuries as traditional natural remedies. Approximately $80 \%$ of the global population commonly depends on the medicinal plants as they are inexpensive and easy to obtain and they may use them along with synthetic medicines, especially in developing regions (Mbuni et al., 2020). The phytochemical constituents of these plants proved their therapeutic efficacy against wide range of pathogens (Škrovánková et al., 2012).

$R$. graveolens has been known to be one of the important herbal medicines which is considered a rich source of natural bioactive substances including alkaloids, volatile oils, coumarins, and phenolic acids and flavonoids. The extracts (alcohol and aqueous) and volatile oils of $R$. graveolens have shown antimicrobial, 
anthelmintic and antiparasitic properties besides acting as antiphlogistic, antipyretic, antidiarrheal, anti-rheumatic, analgesic (Orlanda \& Nascimento, 2015; Malik et al.,2017).

The findings of the present study demonstrated the antibacterial effect of $R$. graveolens extract on gram negative and gram positive bacteria. The ethanol extract of leaves showed a very close effect on all tested bacteria (Figure1). E.coli was the most sensitive bacteria among all the strains to the leaves extract with maximum inhibition zone $(15.3 \mathrm{~mm})$ at concentration of $100 \mathrm{mg} / \mathrm{ml}$. However, the concentration of $20 \mathrm{mg} / \mathrm{ml}$ did not show any inhibition. This result comes in agreement with Amabye \& Shalkh (2015) where they found that the ethanolic extraction of $R$. graveolens leaves has a significant effect on E.coli. S. pyogenes reported high inhibition zone $(9 \mathrm{~mm})$ at 100 $\mathrm{mg} / \mathrm{ml}$. Similar to E.coli, the $20 \mathrm{mg} / \mathrm{ml}$ concentration exhibited a weak effect with inhibition zone of $(1 \mathrm{~mm})$ (Table 1). These finding may indicate that the effect of ethanol decreases obviously as the dilution increase. In comparison to methanol and chloroform extract that are more effective against bacterial isolates at higher dilutions (Amabye \& Shalkh, 2015). $S$. aureus, E. faecalis and $P$. aeruginosa, experienced relatively the same action of leaves extract with maximum inhibition zones at 100 $\mathrm{mg} / \mathrm{ml}$.

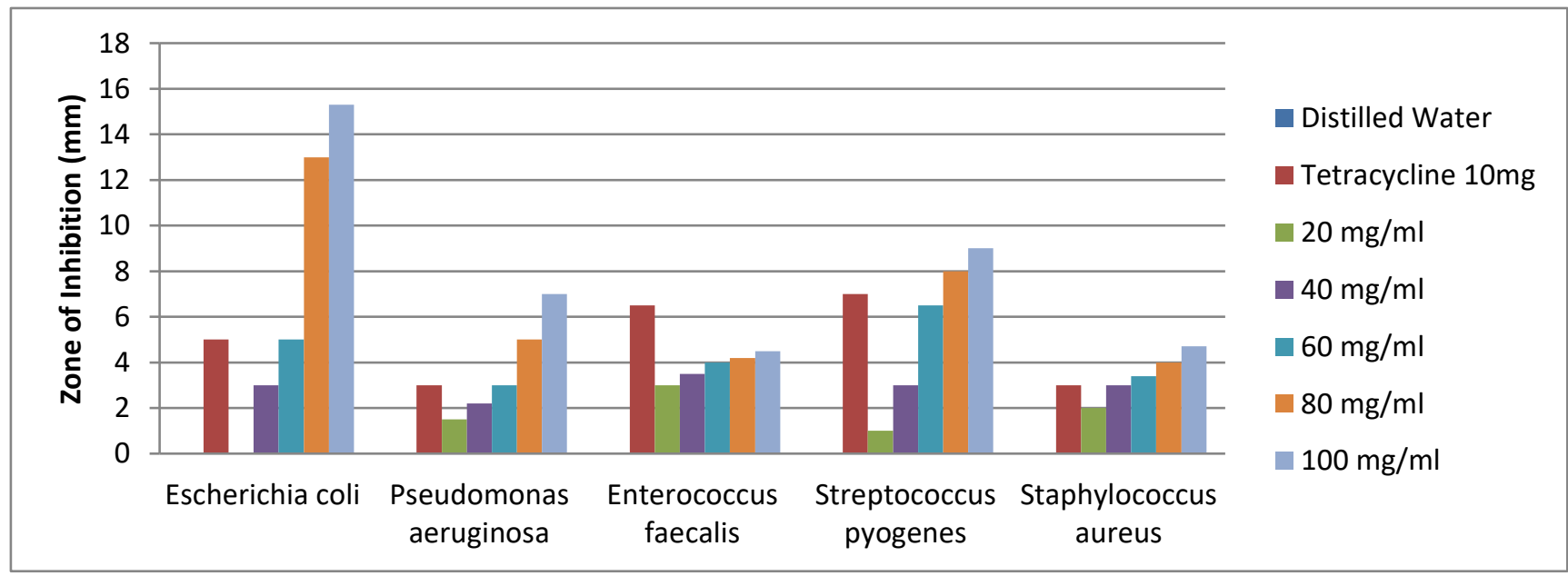

Fig.( 1):- The effects of ethanol extract of leaves on the growth of bacterial strains.

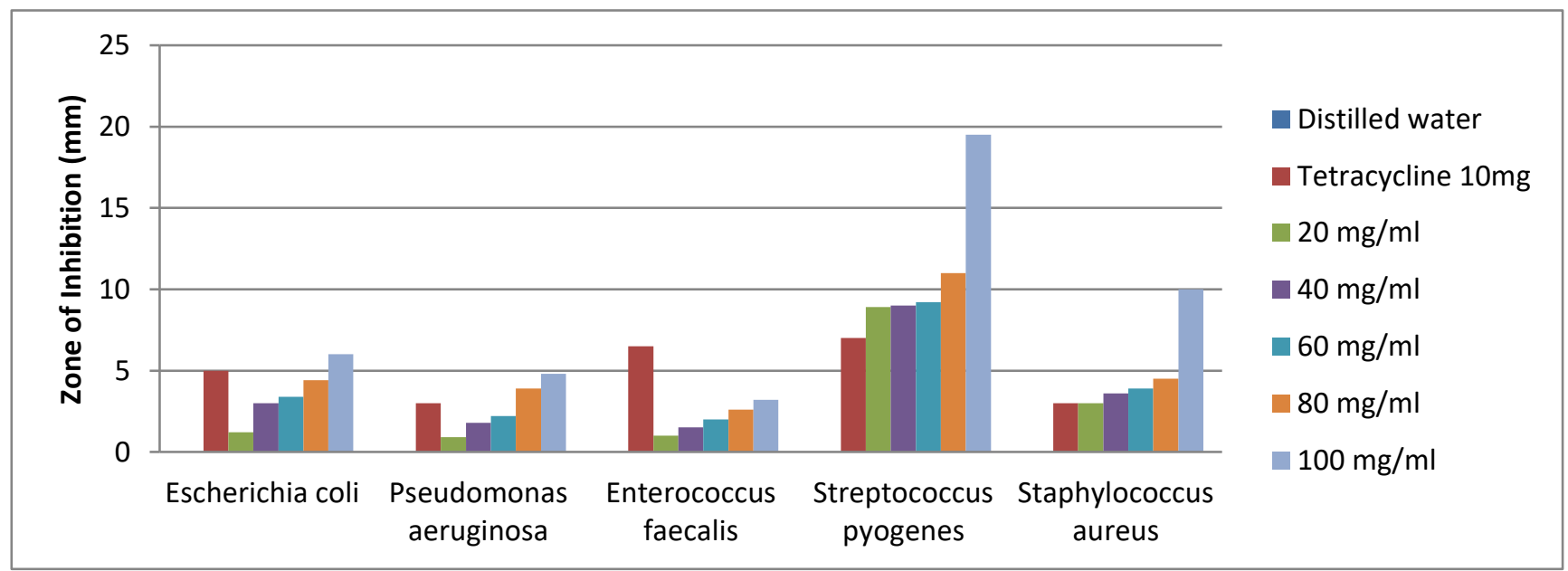

Fig.( 2):- The effects of ethanol extract of stems on the growth of bacterial strains. 
Table( 1):- Descriptive statistics of the effects of the leaves extract on all bacteria

\begin{tabular}{cccccc}
\hline Descriptive statistics & S. pyogenes & S. aureus & E. faecalis & E.coli & P.aeruginosa \\
\hline Mean & 5.5 & 3.42 & 3.84 & 7.26 & 3.74 \\
\hline Standard Deviation & 3.391165 & 1.020784 & 0.594138 & 6.586957 & 2.244549 \\
\hline Standard Error & 1.516575 & 0.456509 & 0.265707 & 2.945777 & 1.003793 \\
\hline Lower 95\% CL Mean & 1.289312 & 2.152529 & 3.10228 & -0.91879 & 0.953024 \\
\hline Upper 95\% CL Mean & 9.710688 & 4.687471 & 4.57772 & 15.43879 & 6.526976 \\
\hline Minimum & 1 & 2 & 3 & 0 & 1.5 \\
\hline Maximum & 9 & 4.7 & 4.5 & 15.3 & 7 \\
\hline
\end{tabular}

Table( 2):- Descriptive statistics of the effects of the stems extract on all bacteria.

\begin{tabular}{cccccc}
\hline Descriptive statistics & $\begin{array}{l}\text { S.pyogene } \\
\boldsymbol{s}\end{array}$ & S. aureus & E. faecalis & E.coli & P.aeruginosa \\
\hline Mean & 11.52 & 5 & 2.06 & 3.6 & 2.72 \\
\hline Standard Deviation & 4.542797 & 2.846928 & 0.870632 & 1.772004 & 1.592796 \\
\hline Standard Error & 2.0316 & 1.273185 & 0.389359 & 0.792465 & 0.71232 \\
\hline Lower 95\% CL Mean & 5.879373 & 1.465072 & 0.978968 & 1.399766 & 0.742282 \\
\hline Upper 95\% CL Mean & 17.16063 & 8.534928 & 3.141032 & 5.800234 & 4.697718 \\
\hline Minimum & 8.9 & 3 & 1 & 1.2 & 0.9 \\
\hline Maximum & 19.5 & 10 & 3.2 & 6 & 4.8 \\
\hline
\end{tabular}

Table( 3):-ANOVA test compares the efficacy of leaves and stem extracts on all bacteria.

\begin{tabular}{|c|c|c|c|c|c|c|}
\hline \multicolumn{3}{|l|}{ Power } & \multicolumn{4}{|c|}{$(\alpha=0.05)$} \\
\hline Between & 1 & 0.6498 & 0.6498 & 0.0427 & 0.83711 & 0.05472 \\
\hline Within (Error) & 48 & 729.9424 & 15.20713 & & & \\
\hline Adjusted Total & 49 & 730.5922 & & & & \\
\hline Total & 50 & & & & & \\
\hline
\end{tabular}

Table( 4):- ANOVA test compares the efficacy of leaves and stem extracts on S. pyogenes and S. aureus, showing the significant effect of stems extract on gram positive bacteria.

\begin{tabular}{|c|c|c|c|c|c|c|}
\hline Power & \multicolumn{6}{|c|}{$(\alpha=0.05)$} \\
\hline Between & 1 & 72.2 & 72.2 & 4.6048 & 0.04577 & 0.52827 \\
\hline Within (Error) & 18 & 282.228 & 15.67933 & & & \\
\hline Adjusted Total & 19 & 354.428 & & & & \\
\hline Total & 20 & & & & & \\
\hline
\end{tabular}

*The NCSS statistical software was used for data analysis.

*Sum of squares (SS), Mean square (MS).

The gram negative bacteria showed less sensitivity to the plant extract in contrast to gram positive bacteria, especially against the stems extract. The resistance mechanism in gram negative bacteria is attributed to their outer membrane which acts as strong barrier. On the contrary, the membrane of gram positive bacteria is more permeable to the diffusion of 
the molecules of antibiotics (Atef et al., 2019). According to previous studies, the volatile oils of the aired parts of the $R$. graveolens reported high antibacterial activity against gram positive bacteria (Orlanda \& Nascimento, 2015; Reddy \& Al-Rajab, 2016). In addition, this study showed the strong action of stems extract against gram positive bacteria. This could indicate that stems extract has the greatest contribution on the inhibition of gram positive strains rather than leaves (Table 4). On the other hand, the findings of Pushpa et al. (2015) disagree with the previous conclusion, where they found that the methanolic extract of the aerial parts of $R$. graveolens has stronger inhibitory action on gram negative bacteria. The strain of bacteria and the type of the solvent that is used for extraction could lead to this contradiction in results (Pushpa et al., 2015). In this study tetracycline $10 \mathrm{mg}$ was used as positive control on all bacterial strains. $E$. faecalis and $S$. pyogenes were the most sensitive bacteria with inhibition zones $(6.5 \mathrm{~mm}$ and $7 \mathrm{~mm}$ ) respectively. $P$. aeruginosa and $S$. aureus were less affected by tetracycline.

The stems extract exhibited a relatively strong action against $S$. pyogenes and $S$. aureus. They were the most sensitive bacteria to the extract (Figure 2). The highest inhibition zones $(8.9 \mathrm{~mm}$ at $20 \mathrm{mg} / \mathrm{ml}, 19.5 \mathrm{~mm}$ at $100 \mathrm{mg} / \mathrm{ml}$ ) were observed in $S$. pyogenes. However, $E$. faecalis, did show resistance to the stems and leaves extracts $(3.2 \mathrm{~mm}$ at $100 \mathrm{mg} / \mathrm{ml}$ and $4.5 \mathrm{~mm}$ at $100 \mathrm{mg} / \mathrm{ml}$ ) respectively. The resistance of E. faecalis to aqueous, ethanol $70 \%$, and methanol extract of $R$. graveolens was also observed by Saeidinia et al. (2016). P. aeruginosa and E.coli were comparatively more resistant to the stem extract. Pandey et al. (2011) documented that the ethanol extract of stems showed a powerful action against $S$. aureus and Bacillus subtilis while $P$. aeruginosa showed high resistance. Considering these findings and the data of this study it can be inferred that $R$. graveolens stems extract has demonstrated its efficacy against gram positive bacteria. The extract of the stem contains alkaloidal, phenolics, tannins, flavonoids and the alkaloids are responsible for the obvious antimicrobial activity against pathogens.

\section{CONCLUSION}

This study showed the antibacterial efficiency of $R$. graveolens extracts against different bacterial strains. These findings and in accord to the previous studies demonstrate the importance of $R$. graveolens as natural antibacterial and prospects for the contribution in pharmaceutical industry.

\section{REFERENCES}

Ahmadi M, Honarmand H, Falah-Delavar S, Saeidinia A. (2012). Study on antibacterial effect of Ruta graveolens extracts on pathogenic bacteria. Annals of Biological Research 3 (9), 4542-4545

Amabye, T. G. \& Shalkh, T.M. (2015). Phytochemical screening and evaluation of antibacterial activity Of Ruta Graveolens L. a medicinal plant grown Around Mekelle, Tigray, Ethiopia. Natural Products Chemistry \& Research, 03(06). doi:10.4172/23296836.1000195

Aronson, J. K. (2016). Rutaceae. Meyler's Side Effects of Drugs, 265-279. doi:10.1016/b9780-444-53717-1.01425-6

Atef, N. M., Shanab, S. M., Negm, S. I., \& Abbas, Y. A. (2019). Evaluation of antimicrobial activity of some plant extracts against antibiotic susceptible and resistant bacterial strains causing wound infection. Bulletin of the National Research Centre, 43(1). doi:10.1186/s42269-019-0184-9

Balouiri, M., Sadiki, M., \& Ibnsouda, S. K. (2016). Methods for in vitro evaluating antimicrobial activity: A review. Journal of Pharmaceutical Analysis, 6(2), 71-79. https://doi.org/10.1016/j.jpha.2015.11.005

Fadlalla, K., Watson, A., Yehualaeshet, T., Turner, T., \& Samuel, T. (2011). Ruta graveolens extract induces DNA damage pathways and blocks Akt activation to inhibit cancer cell proliferation and survival. Anticancer research, 31(1), 233-241.

França Orlanda, J., \& Nascimento, A. (2015). Chemical composition and antibacterial activity Of Ruta Graveolens L. (rutaceae) VOLATILE Oils, from SÃO LUÍS, Maranhão, Brazil. South African Journal

$$
\text { of Botany, 99, 103-106. }
$$
doi:10.1016/j.sajb.2015.03.198

Freire, R. B., Borba, H. R., \& Coelho, C. D. (2010). Ruta graveolens L. toxicity in Vampirolepis nana infected mice. Indian Journal of 
Pharmacology,

42(6),345.https://doi.org/10.4103/0253-

7613.71898

Harish Kumar K, Shanmugavadivu M,

Ranjithkumar R, Selvam K (2014) .

Antibacterial Activity of Different Solvent

Extracts of Medicinal Plant: Ruta

Graveolens L. International Journal of

Biosciences and Nanosciences, 1(1), 9-11.

Kong, Y., Lau, C., Wat, K., Ng, K., But, P., Cheng, K., \& Waterman, P. (1989). Antifertility principle of Ruta graveolens. Planta Medica, 55(02), 176-178. doi:10.1055/s-2006-961917

Malik, S., Moraes, D. F., Do Amaral, F. M., \& Ribeiro, M. N. (2017). Ruta graveolens: Phytochemistry, pharmacology, and biotechnology. Reference Series in Phytochemistry, 177-204. doi:10.1007/978-3319-28669-3_4

Mbuni, Y. M., Wang, S., Mwangi, B. N., Mbari, N. J., Musili, P. M., Walter, N. O., ... Wang, Q. (2020). Medicinal plants and their traditional uses in local communities around Cherangani Hills, Western Kenya. Plants, 9(3), 331. doi:10.3390/plants9030331

Nasirinezhad, F., Ahmadi, A., \& Abrishamifar, S.M. (2016). Effects of the alcoholic extract of Ruta graveolens on spermatogenesis and sex hormones in immature Balb/C mice. Journal of Medical Physiology, 1(2), 78-83.

Pandey, P., Mehta, A., \& Hajra, S. (2011). Evaluation of Antimicrobial Activity of Ruta graveolens Stem Extracts by Disc Diffusion Method. The Journal of Phytology, 3, 92-95.

Pushpa, H., Shree, N., Shetty, S., \& Ramesh, D. (2015). Screening of Antimicrobial , Antioxidant and Anticancer Activity of Ruta graveolens. Advances in Biological Research, 9(4),257-264.

doi:10.5829/idosi.abr.2015.9.94234

Rahim, F., Saki, G., \& Bazrafkan, M. (2009). Effect of alcohol extracts of the ruta graveolens 1 . on the count, motility and in vitro fertilization capacity of rat's sperm. Asian Journal of Plant Sciences, $\quad 9(1), \quad 63-66$. doi:10.3923/ajps.2010.63.66

Ravindran, P., Pillai, G., \& Divakaran, M. (2012). Other herbs and spices: Mango ginger to wasabi. Handbook of Herbs and Spices, 557582. doi:10.1533/9780857095688.557

Reddy, D. N., \& Al-Rajab, A. J. (2016). Chemical composition, antibacterial and antifungal activities of ruta graveolens 1. volatile oils. Cogent Chemistry, 2(1), 1220055. doi:10.1080/23312009.2016.1220055
Ríos, J. (2015). Apoptotic activities of Mediterranean plant species. The Mediterranean Diet, 611620. doi:10.1016/b978-0-12-407849-9.000543

Sailani, M., \& Moeini, H. (2007). Effect of Ruta graveolens and Cannabis sativa alcoholic extract on spermatogenesis in the adult wistar male rats. Indian Journal of Urology, 23(3), 257. doi:10.4103/0970-1591.33720

Tobyn, G., Denham, A., \& Whitelegg, M. (2011). Ruta graveolens, rue. Medical Herbs, 283295. doi:10.1016/b978-0-443-10344-5.00032$\mathrm{X}$

Woo, C. S., Lau, J. S., \& El-Nezami, H. (2012). Herbal medicine. Advances in Botanical Research, 62, 365-384. doi:10.1016/b978-012-394591-4.00009-x

Saeidinia A, Keihanian F, Delavar SF, Keihanian F, Ranjbar A, Karkan MF. (2016). Lack of antibacterial activity of Ruta graveolens extracts against Enterococcus fecalis. Pakistan Journal of Pharmaceutical Sciences, 29(4), 1371-1374

Škrovánková, S., Mišurcová, L., \& Machů, L. (2012). Antioxidant activity and protecting health effects of common medicinal plants. Advances in Food and Nutrition Research Volume 67, 67, 75-139. doi:10.1016/b978-012-394598-3.00003-4 